\title{
Budidaya Bawang Merah (Allium ascalonicum L.) pada Lahan Kering Menggunakan Irigasi Sprinkler pada berbagai Volume dan Frekuensi
}

\author{
Shallot (Allium ascalonicum L.) Cultivation on Dry Land Using Sprinkler Irrigation \\ on Various Volume and Frequency
}

\author{
Rahmi Fauziah $^{1}$, Anas D. Susila ${ }^{1 *}$, dan Eko Sulistyono ${ }^{1}$ \\ Diterima 21 Januari 2016/Disetujui 16 Maret 2016
}

\begin{abstract}
Shallot is one of important commodity besides chili and potatoes. Shallot is cultivated on dry land. The dry land used in Indonesia is still relatively small, while the potential of this area is considered large for the development of agriculture. Pressurized irrigation system has the advantage of efficient use of water making it suitable to be applied on dry land. The study consisted of two experiments, the effect of irrigation volume and frequency of irrigation influence on the growth of shallot. The research was conducted at the Experimental Station Teaching Farm and Postharvest Laboratory Department of Agronomy and Horticulture, Bogor Agricultural University from October 2014 to April 2015. The research consisted of two experiments by using a Randomized Block Design with four replications. The treatment in the first experiment was percentage of the volume of irrigation water consisting of five levels (S100\% ETc, S75\% ETc, S50\% ETc, S25\% ETc (with sprinkler) and 100\% ETc conventional (without sprinkler). The treatment in the second experiment was frequency of irrigation consisting of four levels (two times a day, once a day, once in two days one and once in three days). Results of the first experiment showed the plants could grow and produced up to $525 \%$ ETc or $81.17 \%$ water available for evapotranspiration, but the best treatment was $5100 \%$ ETc volume irrigation, based on yields. Watering with sprinkler irrigation provided better effect than manual watering which was usually done by farmers. The second eperiment showed that the best watering frequency for vegetative growth was once a day while for total yield was twice a day.
\end{abstract}

Key words: dryland, irrigation, shallot, sprinkler, total yield, vegetative growth,

\begin{abstract}
ABSTRAK
Bawang merah salah satu komoditas unggulan nasional selain cabai dan kentang. Budidaya bawang merah umumnya dilakukan pada lahan kering dan membutuhkan irigasi. Sistem irigasi bertekanan memiliki keunggulan dalam efisiensi penggunaan air sehingga cocok untuk diterapkan pada lahan kering. Penelitian terdiri atas dua percobaan, yaitu pengaruh volume irigasi dan pengaruh frekuensi irigasi terhadap pertumbuhan dan produksi bawang merah. Penelitian ini dilaksanakan di Kebun Percobaan Teaching Farm dan Laboratorium Pascapanen Departemen Agronomi dan Hortikultura, Institut Pertanian Bogor dari Oktober 2014 sampai April 2015. Penelitian terdiri atas dua percobaan menggunakan Rancangan Acak Kelompok dengan empat ulangan. Perlakuan pada percobaan 1 adalah persentase volume air irigasi terdiri atas 5 taraf (S100\% ETc, S75\% ETc, S50\% ETc, S25\% ETc (dengan sprinkler) dan konvensional 100\% ETc (tanpa sprinkler), sedangkan perlakuan pada percobaan 2 adalah frekuensi irigasi terdiri atas 4 taraf yaitu dua kali sehari, satu kali sehari, dua hari sekali, tiga hari sekali. Hasil percobaan menunjukkan tanaman masih dapat tumbuh dan berproduksi sampai volume irigasi S25\% ETc atau $81.17 \%$ air tesedia sudah dievapotranspirasikan oleh tanaman, tetapi perlakuan terbaik ialah volume irigasi S100\% ETc
\end{abstract}


berdasarkan bobot panen total. Penyiraman dengan irigasi sprinkler memberikan efek yang sama bahkan lebih baik dibanding penyiraman secara manual yang biasa dilakukan oleh petani. Frekuensi penyiraman terbaik untuk pertumbuhan vegetatif adalah satu kali sehari sementara untuk bobot panen total adalah dua kali sehari.

Kata kunci: bawang merah, hasil total, irigasi, lahan kering, pertumbuhan vegetatif, sprinkler

\section{PENDAHULUAN}

Bawang merah (Allium ascalonicum L.) mempunyai prospek pasar yang baik sehingga termasuk dalam komoditas unggulan nasional. Bawang merah merupakan salah satu komoditas strategis, karena sebagian besar masyarakat Indonesia membutuhkan terutama untuk bumbu masak sehari-hari sehingga mempengaruhi makro ekonomi dan tingkat inflasi (Handayani, 2014). Pemanfaatan lahan kering di Indonesia relatif masih sedikit, sedangkan potensi lahan yang dianggap marjinal itu cukup besar untuk pengembangan pertanian. Pertanian pada lahan kering memerlukan irigasi. Penggunaan air irigasi dapat ditingkatkan dengan mengurangi pemberian air yang lebih rendah dari biasanya sampai tanaman mengalami stres ringan tetapi memberikan dampak minimal terhadap hasil (Zayton, 2007).

Tujuan utama penentuan waktu dan jumlah pemberian air irigasi yang tepat dalam rangka peningkatan efisiensi irigasi (Poerwanto dan Susila, 2014). Air sering merupakan faktor pembatas bagi pertumbuhan tanaman, terutama di daerah kering. Penelitian Samson dan Tilahun (2007) menunjukkan terjadi peningkatan efisiensi penggunaan air oleh tanaman bawang merah dari $6 \%$ menjadi $13 \%$ pada kondisi kebutuhan air 75\% ETc. Balai Penelitian Tanah (2009) menyatakan kelebihan teknologi irigasi sprinkler dapat menghemat air sampai $50 \%$ dibanding cara gelontor. Irigasi sprinkler meningkatkan efisiensi irigasi dan efisiensi penggunaan air pada tanaman bawang dibandingkan dengan metode irigasi permukaan (Kumar et al., 2007). Penggunaan irigasi tetes pada tanaman bawang merah terbukti mampu memenuhi kebutuhan air pada zona akar, meningkatkan efisiensi penggunaan air dan meningkatkan penggunaan nitrogen (Halvorson et al., 2008). Tanaman bawang merah memiliki sistem perakaran yang dangkal dan sangat rentan terhadap hilangnya kelembaban dari lapisan atas tanah sehingga irigasi atau pengairan tambahan yang efisien harus disediakan untuk mempertahankan pertumbuhan (Patel dan Rajput, 2013).

Penelitian ini menggunakan metode pemberian air berdasarkan ETc sesuai dengan kondisi iklim daerah penelitian seperti pada penelitian Samson dan Tilahun (2007) dan Kumar et al. (2007). Penelitian ini bertujuan untuk mendapatkan informasi kebutuhan air pada tanaman bawang merah dengan mempelajari kebutuhan air minimum pada bawang merah dan mengetahui frekuensi penyiraman yang tepat pada bawang merah.

\section{BAHAN DAN METODE}

Penelitian ini dilaksanakan di Kebun Percobaan Teaching Farm dan Laboratorium Pascapanen, Departemen Agronomi dan Hortikultura, Institut Pertanian Bogor dari bulan Oktober 2014 sampai April 2015 menggunakan umbi bawang merah varietas Bima Brebes. Peralatan yang digunakan ialah spray hose dengan ketebalan $0.2 \mathrm{~mm}$, lebar 50 $\mathrm{mm}$, panjang $200 \mathrm{~m}$, tekanan $0.8-1 \mathrm{~kg} \mathrm{~cm}^{-3}$ dan alat pengatur waktu irigasi tipe Miracle 6 $A C$. Penelitian ini terdiri atas dua percobaan, yaitu pengaruh volume irigasi dan pengaruh frekuensi irigasi terhadap pertumbuhan dan produksi bawang merah.

\section{Pengaruh Volume Irigasi terhadap Pertumbuhan dan Produksi Bawang Merah}

Percobaan 1 rancangan yang digunakan pada penelitian ini adalah RAK satu faktor yaitu persentase volume air irigasi terdiri atas 5 taraf: S 100\% ETc, S 75\% ETc, S 50\% ETc, S 25\% ETc dan K 100\% ETc (S = Sprinkler, K $=$ konvensional) dengan empat ulangan sehingga terdapat 20 satuan percobaan. Petak percobaan dibuat bedengan berukuran $1.5 \times 5$ $\mathrm{m}$ untuk setiap satuan percobaan dengan jarak tanam $20 \mathrm{~cm} \times 20 \mathrm{~cm}$. 
Percobaan ini menggunakan metode FAO Panman untuk menentukan kebutuhan air tanaman dengan menggunakan rumus empirik, yaitu dengan menentukan evapotranspirasi.

\section{$\mathbf{E T c}=\mathbf{E T o} . \mathrm{Kc}$}

Keterangan:

$\mathrm{ETc}=$ evapotranspirasi $(\mathrm{mm} / \mathrm{hari})$;

$\mathrm{ETo}=$ evaporasi referens $(\mathrm{mm} / \mathrm{hari})$;

$\mathrm{Kc}=$ koefisien bawang merah.

Nilai ETo referens ditentukan melalui data iklim yaitu, suhu maksimum $\left({ }^{0} \mathrm{C}\right)$, suhu minimum $\left({ }^{0} \mathrm{C}\right)$, kecepatan angin $(\mathrm{km} / \mathrm{hari})$, kelembaban (\%), lama penyinaran (hari/jam). Data iklim yang digunakan ialah tahun 2013 bersumber pada Stasiun Klimatologi Darmaga, Bogor. Perhitungan dengan menggunakan nilai koefisien tanaman $(\mathrm{Kc})$ bawang merah pada setiap fase tumbuh, didapatkan kebutuhan volume kebutuhan air irigasi sebagaimana disajikan pada Tabel 1.

Aplikasi irigasi menggunakan alat irigasi Miracle tipe $6 \mathrm{AC}$, sehingga diperlukan kalibrasi dari irigasi $\mathrm{L}^{-1}$ per petak per setengah hari ke dalam waktu (menit). Kalibrasi dilakukan dengan mengukur volume air yang dihasilkan oleh spray hose sepanjang $1 \mathrm{~m}$ selama 1 menit. Tiap petak percoban terpasang spray hose sepanjang $5 \mathrm{~m}$, sehingga volume air irigasi yang dihasilkan pada tiap petak selama 1 menit sebanyak $4.675 \mathrm{~L}_{\text {petak }}{ }^{-1}$ menit $^{-1}$. Durasi waktu irigasi disajikan pada Tabel 2. Penyiraman dilakukan dua kali sehari yaitu pada pagi (pukul 08.00 WIB) dan sore hari (pukul 15.00 WIB) dengan irigasi sprinkler menggunakan spray hose, kecuali perlakuan K100\% ETc dengan menggunakan gembor.

\section{Pengaruh Frekuensi Irigasi terhadap Pertumbuhan dan Produksi Bawang Merah}

Percobaan 2 rancangan yang digunakan pada penelitian ini adalah RAK satu faktor yaitu frekuensi irigasi yang terdiri atas 4 taraf: dua kali sehari, satu kali sehari, satu kali tiap dua hari dan satu kali tiap tiga hari. Percobaan ini terdiri atas empat ulangan sehingga terdapat 16 satuan percobaan. Besarnya pemberian air irigasi diberikan sesuai dengan ETc seperti pada Percobaan 1. Pengamatan dilakukan terhadap 10 tanaman contoh pada setiap petak percobaan yang berukuran $1.5 \mathrm{~m} \mathrm{x}$ $5 \mathrm{~m}$ yang ditentukan secara acak. Peubah vegetatif yang diamati terdiri atas: tinggi tanaman, jumlah daun segar. Peubah hasil, terdiri atas bobot panen, jumlah umbi, bobot basah dan bobot kering (tajuk, akar, umbi). Sifat fisik tanah, yakni: kadar air kapasitas lapang, kadar air tersedia dan kadar air titik layu permanen.

Tabel 1. Hasil perhitungan kebutuhan volume air irigasi untuk budidaya bawang merah per $7.5 \mathrm{~m}^{2}$

\begin{tabular}{lrrrrr}
\hline \multirow{2}{*}{ Komponen } & $1-2$ & $3-5$ & $6-8$ & $9-10$ & $11-13$ \\
& \multicolumn{2}{c}{$\ldots \ldots \ldots \ldots \ldots \ldots \ldots \ldots \ldots$ MST $\ldots \ldots \ldots \ldots \ldots \ldots \ldots \ldots \ldots \ldots$} \\
& Awal & Vegetatif & Pembungaan & Pembuahan & Pemasakan \\
\hline Kc bawang Merah & 0.60 & 0.80 & 1.10 & 0.90 & 0.85 \\
ETo (mm/ hari) & 4.20 & 4.20 & 3.38 & 3.38 & 3.00 \\
ETc (mm/ hari) & 2.52 & 3.36 & 3.71 & 3.04 & 2.55 \\
Efisiensi Sprinkler & 0.75 & 0.75 & 0.75 & 0.75 & 0.75 \\
Irigasi (mm/ hari) & 3.40 & 4.50 & 5.00 & 4.10 & 3.40 \\
Irigasi per petak (L/ hari) & 25.20 & 33.60 & 37.13 & 30.38 & 25.50 \\
Irigasi per petak (L/ setengah hari) & 12.60 & 16.80 & 18.56 & 15.19 & 12.75 \\
\hline
\end{tabular}

Keterangan: MST $=$ Minggu setelah tanam

Tabel 2. Durasi irigasi dengan spray hose untuk budidaya bawang merah per $7.5 \mathrm{~m}^{2}$

\begin{tabular}{|c|c|c|c|c|c|c|c|c|c|c|}
\hline Perlakuan & $\begin{array}{c}1-2 \\
\text { MST } \\
\text { (L) }\end{array}$ & $\begin{array}{l}\text { Waktu } \\
\text { (menit) }\end{array}$ & $\begin{array}{c}3-5 \\
\text { MST } \\
(\mathrm{L})\end{array}$ & $\begin{array}{l}\text { Waktu } \\
\text { (menit) }\end{array}$ & $\begin{array}{c}6-8 \\
\text { MST } \\
(\mathrm{L})\end{array}$ & $\begin{array}{r}\text { Waktu } \\
\text { (menit) }\end{array}$ & $\begin{array}{c}9-10 \\
\text { MST } \\
(\mathrm{L})\end{array}$ & $\begin{array}{l}\text { Waktu } \\
\text { (menit) }\end{array}$ & $\begin{array}{c}11-13 \\
\text { MST } \\
(\mathrm{L})\end{array}$ & $\begin{array}{c}\text { Waktu } \\
\text { (menit) }\end{array}$ \\
\hline S100\% ETc & 12.6 & 6.0 & 16.8 & 7.0 & 18.6 & 8.0 & 15.2 & 7.0 & 12.8 & 6.0 \\
\hline S75\% ETc & 9.5 & 5.0 & 12.6 & 6.0 & 13.9 & 7.0 & 11.4 & 6.0 & 9.6 & 5.0 \\
\hline S50\% ETc & 6.3 & 4.0 & 8.4 & 5.0 & 9.3 & 6.0 & 7.6 & 5.0 & 6.4 & 4.0 \\
\hline $\mathrm{S} 25 \% \mathrm{ETc}$ & 3.2 & 3.0 & 4.2 & 4.0 & 4.6 & 5.0 & 3.8 & 4.0 & 3.2 & 3.0 \\
\hline $\mathrm{K} 100 \%$ ETc & 12.6 & & 16.8 & & 18.6 & & 15.2 & & 12.8 & \\
\hline
\end{tabular}

Keterangan: $\mathrm{S}=$ sprinkler $; \mathrm{K}=$ kovensional 


\section{HASIL DAN PEMBAHASAN}

\section{Pengaruh Volume Irigasi terhadap Pertumbuhan dan Produksi Bawang Merah}

Berdasarkan hasil analisis tanah didapatkan nilai kadar air kapasitas lapang (KL) sebesar $56.62 \%$ dan kadar air titik layu permanen (TLP) sebesar 42.67\%. Air digunakan oleh tanaman untuk melangsungkan proses pembelahan dan pembesaran sel yang terlihat dari pertambahan tinggi tanaman, diameter, perbanyakan daun dan pertumbuhan akar (Sinaga, 2008). Tinggi tanaman dengan pemberian air irigasi sistem sprinkler (Tabel 3) menunjukkan pengaruh yang lebih baik dibandingkan penyiraman secara konvensional pada awal (2 MST) pertumbuhan tanaman. Perlakuan volume irigasi air baik dengan irigasi sprinkler maupun secara konvensional tidak berbeda nyata terhadap pertumbuhan jumlah daun (Tabel 4).

Tanaman bawang merah umur 5 sampai 8 MST masuk pada proses pembentukan dan pengisian umbi. Pertumbuhan tinggi dan daun akan menurun dikarenakan hasil fotosintesis digunakan untuk pembentukan dan pengisian umbi. Pertumbuhan umbi selanjutnya akan ditentukan oleh jumlah daun yang sudah ada sebelumnya. Al-Moshileh (2007) menyatakan meningkatnya kandungan kadar air tanah akan meningkatkan pertumbuhan tinggi tanaman, jumlah daun dan diameter umbi pada tanaman yang diuji. Tabel 4 dan 5 menunjukkan perlakuan $100 \%$ ETc meningkatkan tinggi tanaman dan jumlah daun segar. Hal ini sesuai dengan penelitian Leskovar et al. (2012) yang menyatakan irigasi $100 \%$ ETc meningkatkan jumlah daun dan tinggi tanaman dibandingkan $75 \%$ ETc dan $50 \%$ ETc.

Tabel 5 menunjukkan perlakuan persentase volume irigasi baik dengan sprinkler maupun secara konvensional berpengaruh terhadap bobot panen total. Rendahnya volume irigasi diikuti rendahnya bobot panen total. Volume irigasi antara $100 \%$ ETc, $75 \%$ ETc, $50 \%$ ETc dan $25 \%$ ETc dengan sistem sprinkler tidak berbeda nyata. Perlakuan volume irigasi tidak mempengaruhi jumlah umbi bawang merah.

Proses pembentukan dan pengisian umbi merupakan tahapan pertumbuhan yang sangat sensitif terhadap cekaman air (Vetayasuporn, 2006). Tingkat irigasi yang semakin menurun, maka transpirasi juga menurun dan produksi menurun (Sulistyono dan Yanuar, 2007). Menurut Russo (2008) jumlah umbi pertanaman dipengaruhi oleh densitas dan varietas tanaman.

Tabel 3. Tinggi tanaman bawang merah pada beberapa taraf perlakuan persentase volume air irigasi

\begin{tabular}{llccc}
\hline \multirow{2}{*}{ Perlakuan } & \multicolumn{4}{c}{ Tinggi Tanaman $(\mathrm{cm})$} \\
\cline { 2 - 5 } & $2 \mathrm{MST}$ & $4 \mathrm{MST}$ & $6 \mathrm{MST}$ & $8 \mathrm{MST}$ \\
\hline S100\% ETc & $17.39 \mathrm{~b}$ & 24.59 & 25.36 & 24.15 \\
S75\% ETc & $17.46 \mathrm{~b}$ & 24.98 & 25.55 & 22.36 \\
S50\% ETc & $18.11 \mathrm{ab}$ & 25.16 & 24.49 & 18.87 \\
S25\% ETc & $19.65 \mathrm{a}$ & 25.89 & 26.03 & 22.45 \\
K100\% ETc & $15.61 \mathrm{c}$ & 23.40 & 22.89 & 20.10 \\
\hline \multicolumn{1}{c}{ Uji F } & $\mathrm{n}$ & tn & tn & tn
\end{tabular}

Keterangan: MST $=$ Minggu setelah tanam ; $\mathrm{n}$ menunjukkan perlakuan berpengaruh sangat nyata, tn menunjukkan perlakuan tidak berpengaruh nyata pada Uji F dengan $\alpha=5 \%$.

Tabel 4. Jumlah daun tanaman bawang merah pada beberapa taraf perlakuan persentase volume air irigasi

\begin{tabular}{lcccc}
\hline \multirow{2}{*}{ Perlakuan } & \multicolumn{4}{c}{ Jumlah Daun Segar (helai) } \\
\cline { 2 - 5 } & 2 MST & 4 MST & 6 MST & 8 MST \\
\hline S100\% ETc & 11.4 & 14.0 & 12.9 & 9.1 \\
S75\% ETc & 11.7 & 14.3 & 11.7 & 8.1 \\
S50\% ETc & 12.7 & 14.5 & 10.3 & 6.7 \\
S25\% ETc & 12.4 & 15.3 & 10.2 & 6.9 \\
K100\% ETc & 10.5 & 12.7 & 9.9 & 8.6 \\
\hline \multicolumn{1}{c}{ Uji F } & tn & tn & tn & tn \\
\hline
\end{tabular}

Keterangan: tn menunjukkan perlakuan tidak berpengaruh nyata pada Uji F dengan $\alpha=5 \%$. 
Tabel 5 menunjukkan penurunan bobot panen total seiring dengan berkurangnya volume irigasi, hal ini sesuai dengan penelitian Leskovar et al. (2012) dimana bobot umbi menurun seiring dengan menurunnya volume irigasi pada 50\% dan 75\% ETc dibandingkan dengan $100 \%$ ETc. Perlakuan volume irigasi $100 \%$ ETc dengan sprinkler lebih baik dibandingkan dengan $100 \%$ ETc secara konvensional. Hal ini diduga pada perlakuan konvensional laju perkolasi lebih besar dibanding laju infiltrasi, sehingga air yang dapat diserap tanaman lebih sedikit dibandingkan dengan sprinkler (Tabel 6).

Hasil pengukuran bobot basah dan bobot kering tanaman (Tabel 7) menunjukkan perlakuan berpengaruh terhadap bobot basah akar. Nisbah tajuk/akar meningkat seiring dengan berkurangnya volume irigasi.
Nisbah tajuk/akar mengalami peningkatan seiring dengan penurunan ketersediaan air, karena pada tumbuhan yang mengalami cekaman akan mengalokasikan sebagian besar hasil fotosintesisnya ke organ penyimpanan. Hal ini ditunjukkan dengan tingginya bobot basah dan kering umbi. Sarka et al. (2008) melaporkan irigasi yang lebih rendah sampai batas tertentu meningkatkan efisiensi penggunaan air. Penurunan volume irigasi dengan sprinkler menunjukkan peningkatan berat kering brangkasan. Hal ini tidak sesuai dengan penelitian Swasono (2012) dimana varietas Bima Brebes digolongkan varietas peka terhadap cekaman kekeringan sehingga terjadi penurunan bobot kering brangkasan lebih dari 50\%. Patel dan Rajput (2013) menyatakan bobot kering tanaman bawang merah sangat nyata berkurang pada kondisi defisit air $40 \%$.

Tabel 5. Bobot panen dan jumlah umbi bawang merah pada beberapa taraf perlakuan volume irigasi

\begin{tabular}{lccc}
\hline \multirow{2}{*}{ Perlakuan } & \multicolumn{2}{c}{ Sepuluh Tanaman Contoh } & $\begin{array}{c}\text { Bobot Panen Total } \\
\left(\mathrm{g} \mathrm{7.5m}^{-2}\right)\end{array}$ \\
\cline { 2 - 4 } & Bobot Panen $(\mathrm{g})$ & Jumlah Umbi & $1301.3 \mathrm{a}$ \\
S100\% ETc & 236.33 & 60.33 & $1176.0 \mathrm{a}$ \\
S75\% ETc & 217.71 & 61.00 & $1194.9 \mathrm{a}$ \\
S50\% ETc & 193.27 & 55.33 & $1144.2 \mathrm{a}$ \\
S25\% ETc & 187.49 & 59.67 & $596.3 \mathrm{~b}$ \\
K100\% ETc & 169.68 & 67.33 & $\mathrm{n}$ \\
\hline \multicolumn{1}{c}{ Uji F } & tn & tn & \\
\hline
\end{tabular}

Keterangan: $\mathrm{n}$ menunjukkan perlakuan berpengaruh sangat nyata, tn menunjukkan perlakuan tidak berpengaruh nyata pada Uji F dengan $\alpha=5 \%$.

Tabel 6. Kadar air tersedia yang diserap tanaman pada beberapa taraf perlakuan volume irigasi

\begin{tabular}{cc}
\hline Perlakuan & Air Diserap (\%) \\
\hline S100\% ETc & $24.46 \mathrm{~b}$ \\
S75\% ETc & $100.52 \mathrm{a}$ \\
S50\% ETc & $34.57 \mathrm{~b}$ \\
S25\% ETc & $81.17 \mathrm{a}$ \\
K100\% ETc & $20.47 \mathrm{~b}$ \\
\hline Uji F & Sangat nyata \\
\hline
\end{tabular}

Keterangan: angka yang diikuti oleh huruf yang sama pada kolom yang sama tidak berbeda nyata berdasarkan uji jarak berganda Duncan (DMRT) pada $\alpha=5 \%$.

Tabel 7. Bobot basah dan bobot kering tanaman bawang merah pada berapa taraf perlakuan volume irigasi

\begin{tabular}{lccccccc}
\hline \multirow{2}{*}{ Perlakuan } & \multicolumn{3}{c}{ Bobot Basah $(\mathrm{g})$} & \multicolumn{3}{c}{ Bobot Kering $(\mathrm{g})$} & Nisbah \\
& Tajuk & Umbi & Akar & Tajuk & Umbi & Akar & Tajuk/Akar \\
\hline S100\% ETc & 3.10 & 22.99 & $0.22 \mathrm{~b}$ & 0.33 & 3.40 & 0.05 & 0.08 \\
S75\% ETc & 3.34 & 19.31 & $0.47 \mathrm{a}$ & 0.40 & 3.56 & 0.13 & 0.10 \\
S50\% ETc & 2.68 & 19.12 & $0.60 \mathrm{a}$ & 0.34 & 3.79 & 0.14 & 0.10 \\
S25\% ETc & 3.71 & 23.91 & $0.51 \mathrm{a}$ & 0.46 & 4.07 & 0.11 & 0.13 \\
K100\% ETc & 2.69 & 14.67 & $0.51 \mathrm{a}$ & 0.32 & 2.46 & 0.15 & 0.14 \\
\hline \multicolumn{1}{c}{ Uji F } & tn & tn & $\mathrm{n}$ & tn & tn & tn & tn \\
\hline
\end{tabular}

Keterangan: $\mathrm{n}$ menunjukkan perlakuan berpengaruh sangat nyata, tn menunjukkan perlakuan tidak berpengaruh nyata pada Uji F dengan $\alpha=5 \%$. 


\section{Pengaruh Frekuensi Irigasi terhadap Pertumbuhan Bawang Merah}

Tujuan utama pengaturan jadwal irigasi ialah untuk penghematan air dan mendapatkan produksi maksimum (Sulistyono dan Yanuar, 2007). Percobaan frekuensi irigasi menunjukkan pengaruh terhadap pertumbuhan tinggi tanaman seiring dengan pertambahan umur tanaman. Irigasi satu kali tiga hari menyebabkan penurunan pertumbuhan tinggi tanaman akibat defisit air pada 4 MST hingga panen (Tabel 8). Tabel 9 menunjukkan frekuensi irigasi berpengaruh terhadap pertumbuhan jumlah daun seiring dengan pertambahan umur tanaman. Berdasarkan penelitian Sutrisna dan Surdianto (2007) yaitu pada tanaman ketang, interval pemberian air tidak berbeda nyata pada awal pertumbuhan disebabkan oleh ketersediaan air pada fase vegetatif dengan interval pemberian air tidak mengakibatkan tanaman kekurangan air, sehingga perbedaan laju pertumbuhannya relatif kecil.

Tabel 8 dan 9 menunjukkan perlakuan frekuensi irigasi satu hari satu kali meningkatkan tinggi dan jumlah daun segar tanaman. Pemberian air irigasi yang lebih jarang mengakibatkan ketersedian air bagi tanaman lebih sedikit dibandingkan perlakuan lainnya, sehingga pertumbuhan menjadi lebih rendah. Ketersediaan air pada fase pertumbuhan dan perkembangan tanaman yang tidak terpenuhi menyebabkan stres (cekaman). Stress air terjadi ketika air tidak tersedia untuk menggantikan kehilangan akibat transpirasi sehingga terjadi kelayuan, gangguan pertumbuhan bahkan kematian (FAO, 2007). Schieber et al. (2008) menyatakan frekuensi irigasi yang rendah dapat menurunkan pertumbuhan tanaman sebagai akibat dari kekurangan nutrisi daripada kekurangan air dan frekuensi irigasi yang tinggi dapat mengkompensasi kekurangan nutrisi. Pemberian irigasi setiap hari pada tanaman stroberi memperlihatkan pertumbuhan vegetatif yang lebih baik dibandingkan tanaman yang mendapat irigasi dua hari sekali (Susanto et al., 2010).

Frekuensi irigasi berpengaruh terhadap bobot panen bawang merah (Tabel 10). Tabel 10 menunjukkan semakin tinggi frekuensi penyiraman maka bobot panen total semakin besar. Frekuensi berpengaruh terhadap hasil dan kualitas umbi. Tabel 11 menunjukkan frekuensi irigasi tidak menunjukkan pengaruh baik pada bobot basah maupun bobot kering per bagian tanaman (tajuk, umbi dan akar).

Tabel 8. Tinggi tanaman bawang merah pada berbagai perlakuan frekuensi irigasi

\begin{tabular}{ccccc}
\hline \multirow{2}{*}{ Perlakuan } & \multicolumn{4}{c}{ Tinggi Tanaman $(\mathrm{cm})$} \\
\cline { 2 - 5 } & $2 \mathrm{MST}$ & $4 \mathrm{MST}$ & $6 \mathrm{MST}$ & $8 \mathrm{MST}$ \\
\hline Satu hari dua kali & 22.23 & $32.53 \mathrm{a}$ & $37.44 \mathrm{ab}$ & $31.21 \mathrm{~b}$ \\
Satu hari satu kali & 22.73 & $32.71 \mathrm{a}$ & $38.96 \mathrm{a}$ & $37.13 \mathrm{a}$ \\
Dua hari satu kali & 21.36 & $31.56 \mathrm{ab}$ & $35.55 \mathrm{bc}$ & $27.57 \mathrm{bc}$ \\
Tiga hari satu kali & 21.91 & $30.03 \mathrm{~b}$ & $33.37 \mathrm{c}$ & $24.04 \mathrm{c}$ \\
\hline Uji F & $\mathrm{tn}$ & $\mathrm{n}$ & $\mathrm{sn}$ & $\mathrm{sn}$
\end{tabular}

Keterangan: sn menunjukkan perlakuan berpengaruh sangat nyata, $\mathrm{n}$ menunjukkan perlakuan berpengaruh nyata, $\mathrm{tn}$ menunjukkan perlakuan tidak berpengaruh nyata berdasarkan Uji $\mathrm{F}$ dengan $\alpha=5 \%$.

Tabel 9. Jumlah daun tanaman bawang merah pada berbagai perlakuan frekuensi irigasi

\begin{tabular}{ccccc}
\hline \multirow{2}{*}{ Perlakuan } & \multicolumn{4}{c}{ Jumlah Daun Segar } \\
\cline { 2 - 5 } & $2 \mathrm{MST}$ & 4 MST & $6 \mathrm{MST}$ & $8 \mathrm{MST}$ \\
\hline Satu hari dua kali & 10.2 & 16.9 & $20.1 \mathrm{ab}$ & $11.6 \mathrm{ab}$ \\
Satu hari satu kali & 9.7 & 16.7 & $22.3 \mathrm{a}$ & $14.5 \mathrm{a}$ \\
Dua hari satu kali & 9.6 & 16.2 & $18.3 \mathrm{~b}$ & $10.9 \mathrm{ab}$ \\
Tiga hari satu kali & 10.6 & 17.1 & $18.1 \mathrm{~b}$ & $7.4 \mathrm{~b}$ \\
\hline Uji F & tn & tn & $\mathrm{n}$ & $\mathrm{n}$ \\
\hline Keterangan: n menunjukkan perlakuan berpengaruh nyata, tn menunjukkan perlakuan tidak berpengaruh nyata \\
berdasarkan Uji F dengan $\alpha=5 \%$.
\end{tabular}


Tabel 10. Bobot 10 tanaman contoh dan bobot panen total bawang merah pada berbagai perlakuan frekuensi irigasi

\begin{tabular}{cccc}
\hline \multirow{2}{*}{ Perlakuan } & \multicolumn{2}{c}{ Sepuluh Tanaman Contoh } & $\begin{array}{c}\text { Bobot Panen Total } \\
\left(\mathrm{g} \mathrm{7.5m}^{-2}\right)\end{array}$ \\
\cline { 2 - 3 } & Bobot Panen $(\mathrm{g})$ & Jumlah Umbi & $2812.5 \mathrm{a}$ \\
Satu hari dua kali & $515.50 \mathrm{ab}$ & $50.75 \mathrm{a}$ & $2012.5 \mathrm{~b}$ \\
Satu hari satu kali & $529.75 \mathrm{a}$ & $47.75 \mathrm{a}$ & $1563.8 \mathrm{~b}$ \\
Dua hari satu kali & $401.50 \mathrm{bc}$ & $41.00 \mathrm{ab}$ & $1388.8 \mathrm{~b}$ \\
Tiga hari satu kali & $283.50 \mathrm{c}$ & $31.50 \mathrm{~b}$ & $\mathrm{sn}$ \\
\hline Uji F & $\mathrm{sn}$ & $\mathrm{N}$ & \\
\hline
\end{tabular}

Keterangan: sn menunjukkan perlakuan berpengaruh sangat nyata, $\mathrm{n}$ menunjukkan perlakuan berpengaruh nyata, tn menunjukkan perlakuan tidak berpengaruh nyata berdasarkan Uji F dengan $\alpha=5 \%$.

Tabel 11. Bobot basah dan bobot kering bawang merah pada berbagai perlakuan frekuensi irigasi

\begin{tabular}{lccccccc}
\hline \multirow{2}{*}{ Perlakuan } & \multicolumn{3}{c}{ Bobot Basah $(\mathrm{g})$} & \multicolumn{3}{c}{ Bobot Kering $(\mathrm{g})$} & Nisbah \\
\cline { 2 - 7 } & Tajuk & Umbi & Akar & Tajuk & Umbi & Akar & Tajuk/Akar \\
\hline Satu hari dua kali & 5.78 & 22.68 & 0.50 & 0.71 & 3.88 & 0.12 & 0.18 \\
Satu hari satu kali & 7.23 & 23.83 & 0.51 & 0.89 & 4.02 & 0.11 & 0.23 \\
Dua hari satu kali & 3.24 & 19.25 & 0.49 & 0.49 & 3.14 & 0.11 & 0.16 \\
Tiga hari satu kali & 3.74 & 16.80 & 0.58 & 0.50 & 2.87 & 0.10 & 0.17 \\
\hline Uji F & tn & tn & tn & tn & tn & tn & tn \\
\hline
\end{tabular}

Keterangan: tn menunjukkan perlakuan tidak berpengaruh nyata pada Uji $\mathrm{F}$ dengan $\alpha=5 \%$.

Frekuensi irigasi memiliki peranan yang penting dalam pertumbuhan dan produksi tanaman bawang. Frekuensi irigasi yang tinggi meningkatkan ketersediaan air pada zona perakaran (Mermoud et al., 2005). Ketersediaan air yang kurang pada saat pembentukan dan pembesaran buah akan menyebabkan ukuran buah mengecil dan mengurangi hasil buah (Poerwanto dan Susila, 2014). Perlakuan frekuensi irigasi satu hari satu kali menghasilkan bobot panen tanaman contoh paling tinggi diantara perlakuan lainnya, sedangkan perlakuan frekuensi irigasi dua kali satu hari menghasilkan bobot panen total tertinggi. Hasil penelitian Pejic et al. (2011) menyatakan irigasi satu kali satu hari meningkatkan ketersediaan air pada zona perakaran dan menghasilkan produksi yang tinggi.

\section{KESIMPULAN}

Perlakuan volume irigasi dengan sprinkler $100 \%$ Etc menghasilkan bobot panen tertinggi, meskipun tidak berbeda nyata dengan perlakuan sprinkler lainnya dan berbeda nyata dengan irigasi konvensional $100 \%$ ETc. Tanaman masih dapat tumbuh dan berproduksi dengan normal sampai kebutuhan air $25 \%$ Etc atau $81.17 \%$ air tersedia sudah dievapotranspirasikan oleh tanaman. Pemberian air dengan cara irigasi memiliki pengaruh yang lebih baik dibandingkan pemberian air dengan cara petani, yaitu penyiraman secara konvensional dengan gembor. Frekuensi irigasi terbaik berdasarkan bobot panen total pada penelitian ini ialah sehari dua kali. Frekuensi terbaik berdasarkan pertumbuhan tinggi tanaman, jumlah daun segar dan bobot panen tanaman contoh ialah satu hari satu kali.

\section{DAFTAR PUSTAKA}

Al-Moshileh, A.M. 2007. Effects of planting date and irrigation water level on onion (Allium cepa L.) production under central Saudi Arabian conditions. Scie. J. King Faisal University (Basic and Applied Sciences). 8(1): 75-85.

[BPT] Balai Penelitian Tanah. 2009. Teknik irigasi diminati petani bawang Donggala. Warta Penelitian dan Pengembangan Pertanian. 31(6): 1-19.

[FAO] Food and Agriculture Organization. 2007. http://www.fao.org. [11 Juli 2009].

Halvorson, A.D., M.E. Bartolon, C.A. Reule, A. Befrada. 2008. Nitrogen effects on onion yield under drip and furrow irrigation. Agron. J. 100: 1062-1069. 
Handayani, S.A. 2014. Optimalisasi Pengelolaan Lahan untuk Sayuran Unggulan Nasional. Julianto, editor. Tabloid Sinar Tani Senin 28 April 2014. http:// tabloidsinartani.com. [12 November 2014].

Kumar, S., M. Imtiyaz, A. Kumar, R. Singh. 2007. Response of onion (Allium cepa L.) to different levels of irrigation water. Agric. Water Manag. 89: 161-166.

Leskovar, D.I., S. Agehara, K. Yoo, N.P. Seva. 2012. Crop coefficient-based deficit irrigation and planting density for onion: growth, yield and bulb quality. HortScience. 47(1): 31-37.

Mermoud, A., T.D. Tamini, H. Yacouba. 2005. Impacts of different irrigation schedules on the water balance components of an onion crop in a semiarid zone. Agric. Water Manag. 77: 282-295.

Patel, N., T.B.S. Rajput. 2013. Effect of deficit irrigation on crop growth, yield and quality of onion in subsurface drip irrigation. Int. J. Plant. Prod. 7(3): 417-436.

Pejic, B., J.G. Varga, S. Milic, A.I. Cupina, D. Krstic, B. Cupina. 2011. Effect of irrigation schedules on yield and water use of onion (Allium cepa L.). African J. Biotech. 10(14): 2644-2652.

Poerwanto, R., A.D. Susila. 2014. Seri 1 Hortikultura Tropika Teknologi Hortikultura. IPB Press. Bogor.

Rachmat, M., B. Sayaka, C. Muslim. 2012. Produksi Perdagangan dan Harga Bawang Merah. http://pse.litbang. pertanian.go.id [19 november 2015].

Russo, V.M. 2008. Plant density and nitrogen fertilizer rate on yield and nutrient content of onion developed from greenhouse-grown transplants. HortScience. 43: 1759-1764.

Samson, B., K. Tilahun. 2007. Regulated deficit irrigation scheduling of onion in a semiarid region of Ethiopia. Agric. Water Manag. 89(1): 148-152.
Sarka, S., S.B. Goswami, S. Mallick, M.K Nanda. 2008. Different indices to characterize water use pattern of microsprinkler irrigated onion (Allium cepa L). Agric. Water Manag. 95: 625-632.

Scheiber, S.M., R.C. Beeson, J. Chen, Q. Wang, B. Pearson. 2008. Evaluation of irrigation frequency and quantity on leaf gas exchange, growth and nitrate leaching of Coleus in a simulated landscape. HortScience. 43(3): 881-884.

Sinaga, R. 2008. Keterkaitan nisbah tajuk akar nisbah tajuk akar dan efisiensi penggunaan air pada rumput gajah dan rumput raja akibat penurunan ketersediaan air tanah. J. Biologi Sumatera. 3(1): 29-35.

Sulistyono, E., S. Yanuar. 2007. Pengaruh jadwal irigasi terhadap pemakaian air konsumtif dan produksi nilam (Pogostemon cablin (Blanco) Benth.). Buletin Agron. 36(1): 64-69.

Susanto, S., B. Hartanti, N. Khumaida. 2010. Produksi dan kualitas buah stroberi pada beberapa sistem irigasi. J. Hort. Indonesia. 1(1): 1-9.

Sutrisna, N., Y. Surdianto. 2007. Pengaruh bahan organik dan interval serta volume pemberian air terhadap pertumbuhan dan hasil kentang di rumah kaca. J. Hort. 17(3): 224-236.

Swasono, F.D.H. 2012. Karakteristik fisiologi toleransi tanaman bawang merah terhadap cekaman kekeringan di tanah pasir pantai. AgriSains. 3(4): 88-103.

Vetayasuporn, S. 2006. Effects of biological and chemical fertilizers on growth and yield of shallot (Allium cepa var. ascolonicum) production. J. Bio.Sci. 6(1): 82-86.

Zayton, A.M. 2007. Effect of soil-water stress on onion yield and quality in sandy soil. Misr J. Ag. Eng. 24(1): 141-160. 